J. Perinat. Med. 14 (1986) 127

\title{
Rapid sexing of native amniotic cells by hybridization to a cloned, $Y$ chromosome DNA probe
}

\author{
Peter Wieacker ${ }^{1}$, Clemens R. Müller ${ }^{2}$, and Jan W. Siebers ${ }^{1}$ \\ ${ }^{1}$ Department of Obstetrics and Gynecology, University Clinic, Freiburg, and \\ ${ }^{2}$ Institute for Human Genetics, University of Wuerzburg, Fed. Rep. Germany
}

\section{Introduction}

Closely linked restriction fragment length polymorphisms (RFLPs) are useful markers of genetic defects and can be employed for prenatal diagnosis (for a review see BotsTEIN et al., [2]). Recently linkage studies between polymorphic DNA sequences and several loci of X-linked disorders have been performed $[4,13,14,15$, $3,1,8]$. In most cases of $\mathrm{X}$-linked disorders, a prenatal diagnosis is not yet possible. In these cases fetal sex determination is very useful. The conventional procedure for chromosome analysis of amniotic cells takes at least 2 weeks. In this paper we describe a technique of fetal sex determination by means of a Y-chromosome DNA sequence that can be employed as a hybridization probe for uncultered amniotic cells. Results can be obtained in 3 days.

\section{Experimental procedure and resulțs}

The DNA clone $\lambda C Y 1$ used in this study was isolated from a genomic $\mathrm{Y}$ chromosome library and has been shown previously to hybridize almost exclusively to the human $\mathrm{Y}$ chromosome by in situ hybridization to metaphase spreads [10]. A second minor binding was seen in the centromeric heterochromatin of chromosome 9.

(C) 1986 by Walter de Gruyter Co. Berlin - New York

\section{Curriculum vitae}

Peter Wieacker, M.D., was born in 1955 in Agadir (Morocco). He obtained his medical degree in 1981. He worked for two years at the Institute for Human Genetics in Freiburg. Presently he is specializing in gynecolgoy and obstetrics at the Universitäts-Frauenklinik in Freiburg. His main fields of interest in-

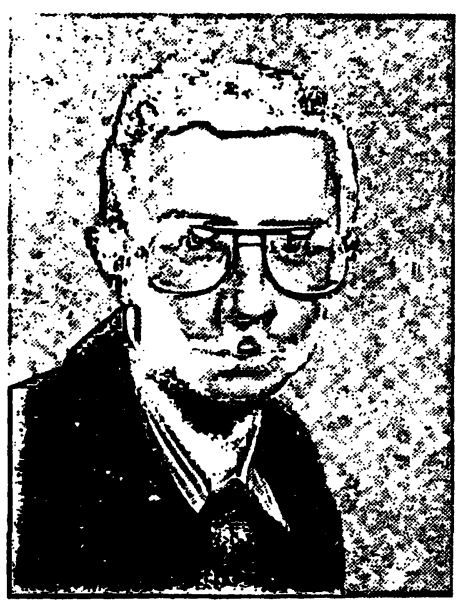
clude prenatal diagnosis of genetic disorders, clinical genetics and recombinant DNA technology.

Fetal cells were obtained by routine amniocentesis in the second trimester from 24 pregnant women who requested fetal karyotyping because of advanced maternal age. Cells were collected from $0.5 \mathrm{ml}$ of amniotic fluid by centrifugation (15 min., $12.000 \mathrm{~g}$ ). The cell pellet was resuspended in $10 \mu \mathrm{l}$ of denaturing solution $(0.5 \mathrm{M} \mathrm{NaOH} ; 1.5 \mathrm{M} \mathrm{NaCl})$ and heated for $10 \mathrm{~min}$. to $100^{\circ} \mathrm{C}$. The samples were spotted onto nitrocellulose filters, baked and hybridized to nick translated $\lambda \mathrm{CY} 1 \mathrm{DNA}\left(1 \mathrm{X} 10^{7} \mathrm{cpm} / \mu \mathrm{g}\right.$ DNA) as described previously [16]. Filters were washed repeatedly in 3XSSC and 1XSSC for $30 \mathrm{~min}$. at $65^{\circ} \mathrm{C}$ and autoradiographed. The 
remainder of the amniotic fluid samples was used for cell culture and karyotyping by standard Q-banding.

All DNA samples which gave strong hybridization signals with $\lambda$ CY1 were subsequently identified to originate from male fetuses (10 of 24; cf. samples 1, 3, 5 and 6 in Fig. 1). None of the 14 female samples did hybridize with comparable intensity (samples 2, 4, 7 and 8 in figure 1). The faint signals observed in some of the female DNAs may be due to the weak binding of $\lambda C Y 1$ to the centromeric heterochromatin of chromosome 9. Under the described hybridization conditions, male DNA samples can be unambiguously identified.

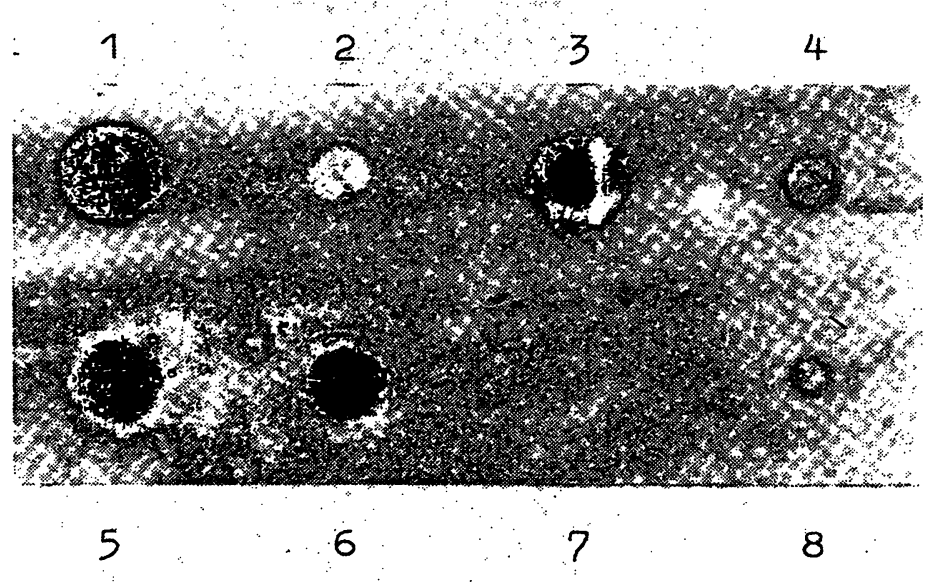

Figure 1. Dot blot hybridization of amniotic fluid cells with the $\lambda C Y 1$ probe. $1,3,5$ and $6:$ male fetuses; $2,4,7$ and 8 : female fetuses.

\section{Discussion}

We describe a rapid screening method for fetal sex determination using a cloned repetitive DNA sequence from the human $Y$ chromosome as hybridization probe. No culture of amniotic cells is needed prior to analysis. Thus, results can be obtained within 3 days instead of $2-3$ weeks which are usually required for standard karyotyping. As little as $0.5 \mathrm{ml}$ of amniotic fluid is used for this analysis, preserving the remainder of the sample for biochemical or cytogenetic assays as required.

Fetal sexing with other $Y$-specific repetitive DNA clones has been reported using fetal cells from amniocentesis or chorion biopsy material $[5,6,7,9,11,12]$. At present, chorion biopsy seems still to have a greater risk than second trimester amniocentesis and may not be applicable in all cases. Indeed, chorion biopsy must be performed between the eigth and tenth week of the pregnancy, in a time in which many women do not know that they are pregnant. It is likely that second trimester amniocentesis will continue to serve as important source of fetal cells for some time to come.

Fetal sex determination by cloned repetitive DNA fragments which originate from the heterochromatic part of the human Y chromosome has met one major concern. Due to the high variability of $\mathrm{Y}$ heterochromatin in human males false negative results may be obtained when dealing with minute $\mathrm{Y}$ chromosome variants if such variants are entirely devoid of heterochromatin. To rule out possible confusion it is therefore recommended to analyze the father's chromosome prior to amniocentesis. Furthermore, because of weak binding of $\lambda \mathrm{CY} 1$ to the centromeric heterochromatin of chromosome 9 , it is also recommendable to test with the fetal cells reference DNAs in order to exclude false positive results.

\section{Summary}

A cloned DNA fragment from a Y chromosome genomic library was used for prenatal sex determination. Native cells from as little as $0.5 \mathrm{ml}$ of amniotic fluid were analyzed by a dot blot hybridization technique without prior cell culture. Identification of male fetuses was possible within 3 days and confirmed by subsequent conventional karyotyping. This method of rapid sex

screening is an alternative to the other methods of prenatal determination to the conventional chromosome analysis because it is a more rapid method, and to the karyotyping of chorion biopsy material because amniocentesis seems to have a lower risk and can still be performed when chorion biopsy is not more possible.

Keywords: Amniotic fluid cells, fetal sex determination, prenatal diagnosis, recombinant DNA technology. 


\section{Zusammenfassung}

Schnelle fetale Geschlechtsbestimmung an Aminiozyten mit Hilfe einer Y-spezifischen DNA Sequenz

Ein kloniertes DNA-Fragment aus einer Y-Chromosomenbank wurde zur pränatalen Geschlechtsbestimmung verwendet. Native Amniozyten aus $0,5 \mathrm{ml}$ Fruchtwasser wurden nach der Hybridisierung-Tropftechnik ohne vorige Zellkultur analysiert. Eine sichere Geschlechtsbestimmung konnte nach 3 Tagen erfolgen. Diese Ergebnisse wurden durch konventionelle Chromosomenanalyse bestätigt. Diese Methode der pränatalen Geschlechtsbe- stimmung ist eine Alternative zu den bisherigen Methoden. Sie ist schneller als die Chromosomenanalyse aus Zellkulturen. Gegenüber der Chorionbiopsie bietet sie einerseits den Vorteil, da $\beta$ die Gewinnung fetaler Zellen durch die Amniozentese weniger risikoreich zu sein scheint als die Chorionbiopsie, und andererseits, daß diese Methode immer noch angewendet werden kann, wenn eine Chorionbiopsie aus Zeitgründen nicht mehr möglich ist.

Schlüsselwörter: Amniozyten, prenatale Diagnose, rekombinante Gentechnologie, vorgeburtliche Geschlechtsbestimmung.

\section{Résumé}

Détermination rapide du sexe sur des cellules d'origine amniotique par hybridation avec une sonde $A D N$ spécifique du chromosome $Y$ obtenue par clonage

Un fragment d'ADN, provenant d'une banque de chromosomes $\mathrm{Y}$, a été utilisé comme sonde pour le diagnostic prénatal du sexe fotal. Les cellules provenant de $0,5 \mathrm{ml}$ de liquide amniotique ont été analysées par la méthode d'hybridation sans culture préalable des cellules. Au bout de 3 jours, un diagnostic exact est possible. Les résultats obtenus ont été confirmés par une analyse conventionnelle des chromosomes. Il s'agit donc d'une alternative aux autres techniques déjà établies pour le diagnostic prénatal du sexe. Elle est plus rapide que l'analyse conventionnelle des chromosomes. Par rapport à la biopsie du chorion, cette méthode a deux avantages. Le risque d'un avortement après amniocentèse semble être moins grand qu'après biopsie du chorion. De plus, cette méthode peut être encore appliquée alors qu'une biopsie du chorion n'est plus possible à cause du terme.

Mots-clés: Diagnostic prénatal du sexe, liquide amniotique, technique de recombinaison de l'ADN.

Acknowledgements: The authors wish to thank Dr. WeRnER SCHEMPP (Freiburg) for chromosome analysis.

\section{References}

[1] Bhattacharya, S. S., A. F. Wright, J. F. Clayton, W. H. Price, C. I. Philips, C. M. E. McKeown, M. Jay, A. C. Bird, P. L. Pearson, E. M. SOUTHERN, H. J. Evans: Close genetic linkage between $\mathrm{X}$-linked retinitis pigmentosa and a restriction fragment length polymorphism identified by recombinant DNA probe L 1.28. Nature 309 (1984) 253

[2] Botstein, D., R. L. White, M. Skolnick, R. W. DAVIS: Construction of a genetic linkage map using restriction fragment length polymorphisms. Am. J. Hum. Genet. 32 (1980) 314

[3] Camerino, G., M. G. Mattei, J. F. Mattei, M. JAY, L. L. MANDEL: Close linkage of fragile Xmental retardation syndrome to haemophilia $B$ and transmission through a normal male. Nature 306 (1983) 701

[4] Davies, K. E., P. L. Pearson, P. S. Harper, J. M. Murray, I. O'Brien, M. Sarfarazi, R. WilliamsoN: Linkage analysis of two cloned DNA se- quences flanking the Duchenne muscular dystrophy locus on the short arm of the human $X$ chromosome. Nucleic Acids Res. 11 (1983) 2303

[5] Gosden, J. R., A. R. Mrtchell, C. M. Gosden: Direct vision chorion biopsy and chromosome-specific DNA probes for determination of fetal sex in first-trimester prenatal diagnosis. Lancet (1982) 1416

[6] Gosden, J. R., S. Christie, C. M. Gosden, J. M. MoRSMAN, C. H. RodeCK: Rapid fetal sex determination in first trimester prenatal diagnosis by dot hybridisation of DNA probes. Lancet I (1984) 540

[7] Hoar, D. I., D. B. Haslam, D. M. StaroziK: Improved direct molecular diagnosis and rapid fetal sexing. Pren. Diagn. 4 (1984) 241

[8] Kingston, H. M., M. Sarfarazi, N. S. T. Thomas, P. S. HARPER: Localisation of the Becker muscular dystrophy gene on the short arm of the $\mathrm{X}$ chromosome by linkage to cloned DNA sequences. Hum. Genet. 67 (1984) 6 
[9] Lau, Y. F., J. C. Huang, A. M. Dozy, Y. W. Kan: A rapid screening test for antenatal sex determination. Lancet (1984) 14

[10] Müller, C. R., K. E. Davies, C. Cremer, G. RaPPOLD, J. W. GRAY, H. H. Ropers: Cloning of genomic sequences from the human $\mathrm{Y}$ chromosome after purification by dual beam flow sorting. Hum. Genet. 64 (1983) 110

[11] Simoni, G., B. Brambati, C. Danesino, G. L. Terzoli, L. Romitti, F. Rossella, M. Fraccaro: Diagnostic application of first trimester trophoblast sampling in 100 pregnancies. Hum. Genet. 66 (1984) 252

[12] Vergnand, G., L. Kaplan, J. Weissenbach, Y. Dumez, R. Berger, P. Thollais, G. Guellaen: Rapid and early determination of sex using trophoblast biopsy specimens and $Y$ chromosome specific DNA probes. Br. Med. J. 289 (1984) 73

[13] Wieacker, P., K. E. Davies, B. Mevorah, H. H. ROPERS: Linkage studies in a family with X-linked recessive ichthyosis employing a cloned DNA sequence from the distal short arm of the $\mathrm{X}$ chromosome. Hum. Genet. 63 (1983) 113
[14] Wieacker, P., N. Horn, P. Pearson, T. F. Wienker, E. MCKAY, H. H. ROPERS: Menkes kinky hair disease: a search for closely linked restriction fragment length polymorphism. Hum. Genet. 64 (1983) 139

[15] Wieacker, P., B. Dallapiccola, K. Bender, K. E. DAVIES, H. H. RoPERS: Linkage relationships between retinoschisis, $\mathrm{Xg}$ and a cloned DNA sequence from the distal short arm of the $\mathrm{X}$ chromosome. Hum. Genet. 64 (1983) 143

[16] Wieacker, P., K. E. Davies, H. J. Cooke, P. PearSON, R. Williamson, S. Bhattacharya, J. Zimmer, H. H. ROPERS: Toward a complete linkage map of the human $\mathrm{X}$ chromosome: regional assignment of 16 cloned single-copy DNA sequences employing a panel of somatic cell hybrids. Am. J. Hum. Genet. 36 (1984) 265

Received January 7, 1985. Revised March 25, 1985. Accepted April 20, 1985.

Peter Wieacker, M. D.

Universitäts-Frauenklinik Freiburg 7800 Freiburg, Hugstetter Straße 55 Fed. Rep. Germany 